\title{
Influence of roadkill during breeding migration on the sex ratio of land crab (Sesarma haematoche)
}

\author{
Mi Ryu ${ }^{1}$ and Jae Geun Kim ${ }^{1,2,3^{*}}$ (D)
}

\begin{abstract}
Adult land crabs generally live on land while their larvae live in the sea. In the case of Sesarma haematoche, female crabs migrate from land to sea to release the larvae at the high tide of syzygy night. Artificial structures along coastal areas are being obstacles for the migration of land crabs and causing synchronized roadkills on coastal roads during breeding migration. In this research, we compared the sex ratios of crab populations in coastal areas with coastal roads and uninhabited island areas with no road. The proportion of females in inland habitats with coastal roads was significantly smaller than island habitats. In particular, females are exposed to the risk of annually repeated roadkills, and the proportion of females decreases rapidly with their growth. If this tendency is general for land crab populations in the coastal areas with roads, significant road mortality of female land crabs during breeding migration can lead to severe population decline in coastal areas. Therefore, it is necessary to take an action to save land crabs crossing coastal roads.
\end{abstract}

Keywords: Breeding migration, Coastal roads, Land crab, Roadkill, Sesarma haematoche, Sex ratio

\section{Introduction}

The coastal roads are expanding rapidly due to the dense human population and seaside town in the coastal area (Sekovski 2012). The expansion of roads has a wide variety of ecological effects (Coffin 2007). Artificial structures create barriers to the movement of organisms and resources (e.g., nutrients, sediments) (Bishop et al. 2017). Therefore, the connectivity of coastal regions as ecotone has reduced and fragmented by artificial structures. These changes may affect local populations (Mumme et al. 2000). Coastal artificial structures, including coastal roads, have a significant impact on the organisms in the transition zone (Airoldi et al. 2015). These structures change the surrounding vegetation and become obstacles to animal movement, even though the transition zone between land and sea is of great biodiversity (Burt 2014).

\footnotetext{
* Correspondence: jaegkim@snu.ac.kr

'Graduate School of Interdisciplinary Program in Environmental Education,

Seoul National University, 1 Gwanak-ro, Gwanak-gu, Seoul 08826, Korea

${ }^{2}$ Department of Biology Education, Seoul National University, 1 Gwanak-ro,

Gwanak-gu, Seoul 08826, Korea

Full list of author information is available at the end of the article
}

Particularly, land crabs are representative animals that are affected significantly by changes in the transition zone and also keystone species for coastal forests and lagoons (Luppi et al. 2001; Lindquist et al. 2009; Paulay and Starmer 2011). Land crabs play major roles in the nutrient cycle because they are moving between two different habitats of larval and adult stages (Miyake et al. 2019), controlling litter decomposition, and predating invertebrates and plants (Paulay and Starmer 2011). Adult land crabs mainly live and copulate on land habitats without tidal effects (Baine et al. 2007). After mating, ovigerous females have to migrate to the sea for releasing larvae annually. After releasing larvae, the female land crabs return to land habitats again. In this process, the female land crabs are confronted with critical roadkill risk on coastal roads. Accordingly, road mortality has been implicated as a significant demographic force in land crabs, particularly for females, which are killed disproportionately on spawning migration (Baine et al. 2007).

(C) The Author(s). 2020 Open Access This article is licensed under a Creative Commons Attribution 4.0 International License, which permits use, sharing, adaptation, distribution and reproduction in any medium or format, as long as you give appropriate credit to the original author(s) and the source, provide a link to the Creative Commons licence, and indicate if changes were made. The images or other third party material in this article are included in the article's Creative Commons licence, unless indicated otherwise in a credit line to the material. If material is not included in the article's Creative Commons licence and your intended use is not permitted by statutory regulation or exceeds the permitted use, you will need to obtain permission directly from the copyright holder. To view a copy of this licence, visit http://creativecommons.org/licenses/by/4.0/. 
The adult sex ratio is important in the animal population (Le Galliard et al. 2005). The number of females is relatively more important than that of males for population growth in the reproduction process and potentially significant in conservation biology (Caswell 2001). In particular, female-biased roadkill during breeding season changes the sex ratio or demographic structure and increases the risk of local extinction (Aresco 2005; Mumme et al. 2000).

We evaluated the potential effect of road mortality on sex ratios of land crab by surveying sex ratios of crabs in the coastal area with roads and uninhabited island without road.

\section{Method}

Sesarma haematocheir is a land crab, which inhabits the lowlands without tidal effect (Saigusa 1978). The ovigerous crabs mainly migrate to coasts to release larvae during the spring tide (new/full moon) in summer (Saigusa 1981; Saigusa and Hidaka 1978). Migration is highly synchronized with nocturnal high tide and with many embryos hatching in $1 \mathrm{~h}$ (Saigusa 2000). Larvae of land crabs live in the sea and young crabs live in mud flat. In the third summer, adult crabs migrate to the land habitats (Suzuki 1981).

This study was conducted in Jinmok (N 34 54' 34', E $\left.127^{\circ} 55^{\prime} 03^{\prime \prime}\right)$ and Wolkok (N $34^{\circ} 55^{\prime} 28^{\prime \prime}$, E $127^{\circ} 51^{\prime}$ $\left.31^{\prime \prime}\right)$ as land crab habitats with coastal roads and Gaeguri Island (N 34 $56^{\prime} 22^{\prime \prime}$, E $127^{\circ} 51^{\prime} 25^{\prime \prime}$ ) and Keunmok Island (N $34^{\circ} 56^{\prime} 00^{\prime \prime}, \mathrm{E} 127^{\circ} 51^{\prime} 28^{\prime \prime}$ ) as land crab habitats without road (Fig. 1). The coastal line in Jinmok is located more closely to the roads than Wolkok. Gaeguri Island and Keunmok Island are uninhabited by humans.

We collected alive crabs using pit-fall traps and fishing net traps at 4 habitats in Aug 2018, June, and July 2019. Traps were installed in places where the crabs were concentrated in the study area. We recorded carapace width and sex of collected crabs. Liu et al. (2017) reported that the smallest ovigerous female had $16.3 \mathrm{~mm}$ carapace width. Suzuki (1981) suggested females smaller than $13.7 \mathrm{~mm}$ carapace width cannot lay eggs. The smallest ovigerous crab in this study had $13.9 \mathrm{~mm}$ carapace width. Therefore, crabs larger than $14 \mathrm{~mm}$ carapace width were considered as sexually mature adults. In order to see the difference in sex ratio according to age, the sex ratio was compared old using a chi-square analysis by dividing a large crab and a small crab based on $18 \mathrm{~mm}$ equivalent to 6 years.

Roadkill data was investigated in Aug 2016, at Seol-

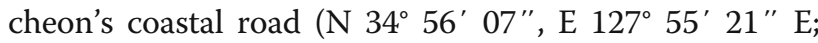
$\mathrm{N} 34^{\circ} 55^{\prime} 18^{\prime \prime}$, E $127^{\circ} 55^{\prime} 30^{\prime \prime}$; $34^{\circ} 53^{\prime} 47^{\prime \prime}, 127^{\circ} 55^{\prime}$ $\left.25^{\prime \prime}\right)$ during spring tide. We counted roadkilled crabs and recorded sex.

\section{Result}

The majority (84\%) of roadkilled land crabs were females on the coastal roads in Seolcheon. Most of roadkilled female crabs were either ovigerous or immediately after spawning (Table 1).

Sex ratios in habitats with coastal roads were significantly more male biased at Jinmok and Wolkok than in
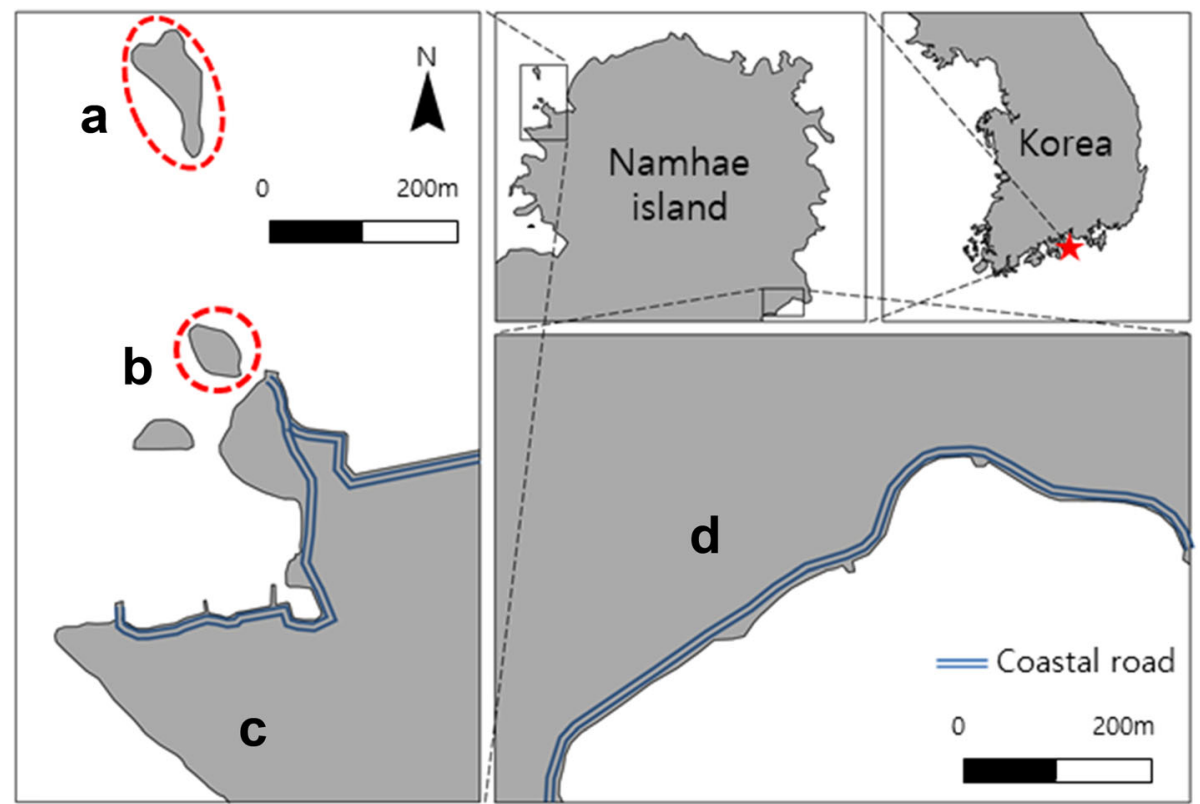

Fig. 1 Study area [without roads, Gaguri Island (a) and Keunmok Island (b); with roads, Wolkok (c) and Jinmok (d)] 
Table 1 Results of chi-square tests on the sex ratio of 4 locations

\begin{tabular}{|c|c|c|c|c|c|c|c|c|}
\hline Location & & Size group & Female & Male & Total & Female (\%) & $X^{2}, \mathrm{df}=1$ & $P$ value \\
\hline \multirow[t]{6}{*}{ Without road } & Gaeguri Island & Juvenile & 28 & 29 & 57 & 49.1 & 0.406 & 0.524 \\
\hline & & Small adult & 20 & 15 & 35 & 57.1 & 0.857 & 0.651 \\
\hline & & Big adult & 16 & 12 & 28 & 57.1 & 0.163 & 0.686 \\
\hline & Keunmok Island & Juvenile & 5 & 8 & 13 & 38.5 & 0.576 & 0.448 \\
\hline & & Small adult & 9 & 12 & 21 & 42.9 & 0.315 & 0.575 \\
\hline & & Big adult & 10 & 5 & 15 & 66.7 & 1.878 & 0.171 \\
\hline \multirow[t]{6}{*}{ With road } & Wolkok & Juvenile & 16 & 9 & 25 & 64.0 & 6.492 & 0.011 \\
\hline & & Small adult & 23 & 23 & 46 & 50.0 & 2.282 & 0.131 \\
\hline & & Big adult & 33 & 80 & 113 & 29.2 & 4.675 & 0.031 \\
\hline & Jinmok & Juvenile & 66 & 82 & 148 & 44.6 & 3.178 & 0.075 \\
\hline & & Small adult & 11 & 12 & 23 & 47.8 & 1.046 & 0.306 \\
\hline & & Big adult & 34 & 91 & 125 & 27.2 & 5.658 & 0.017 \\
\hline
\end{tabular}

other populations in uninhabited islands (Fig. 2; Table 1). Particularly, the proportions of female crab were $29.6 \%$ and $35.2 \%$ in Jinmok and Wolkok, respectively. By contrast, the proportions of female crab were $57.1 \%$ and $54.3 \%$ in Gaeguri Island and Keunmok Island without road, respectively.

The proportion of females decreased with the increase of crab size in habitats with coastal roads. In Jinmok, proportions of juvenile female crab, small female adults, and big female adults were $45 \%, 48 \%$, and only $27 \%$, respectively. Similarly, proportions of juvenile female crab, small female adults, and big female adults in Wolkok were $64 \%, 50 \%$, and only $29 \%$, respectively.

\section{Discussion}

The majority of the roadkilled crabs in this study were females on the coastal roads in Seolcheon during the summer syzygy, when females migrated for spawning (Fig. 2). Many previous studies reported synchronized larval releasing and migration of female land crabs (Saigusa 1981; Paula 1989). The annual breeding migration makes females exposed to greater danger and increased mortality (Hartnoll et al. 2009). The mortality is due to the various predators and getting washed away while releasing larvae (Paulay and Starmer 2011). Some studies documented the possibility of male biased sex ratio caused by natural migration risk in land crabs (Hartnoll et al. 2009). Recently,

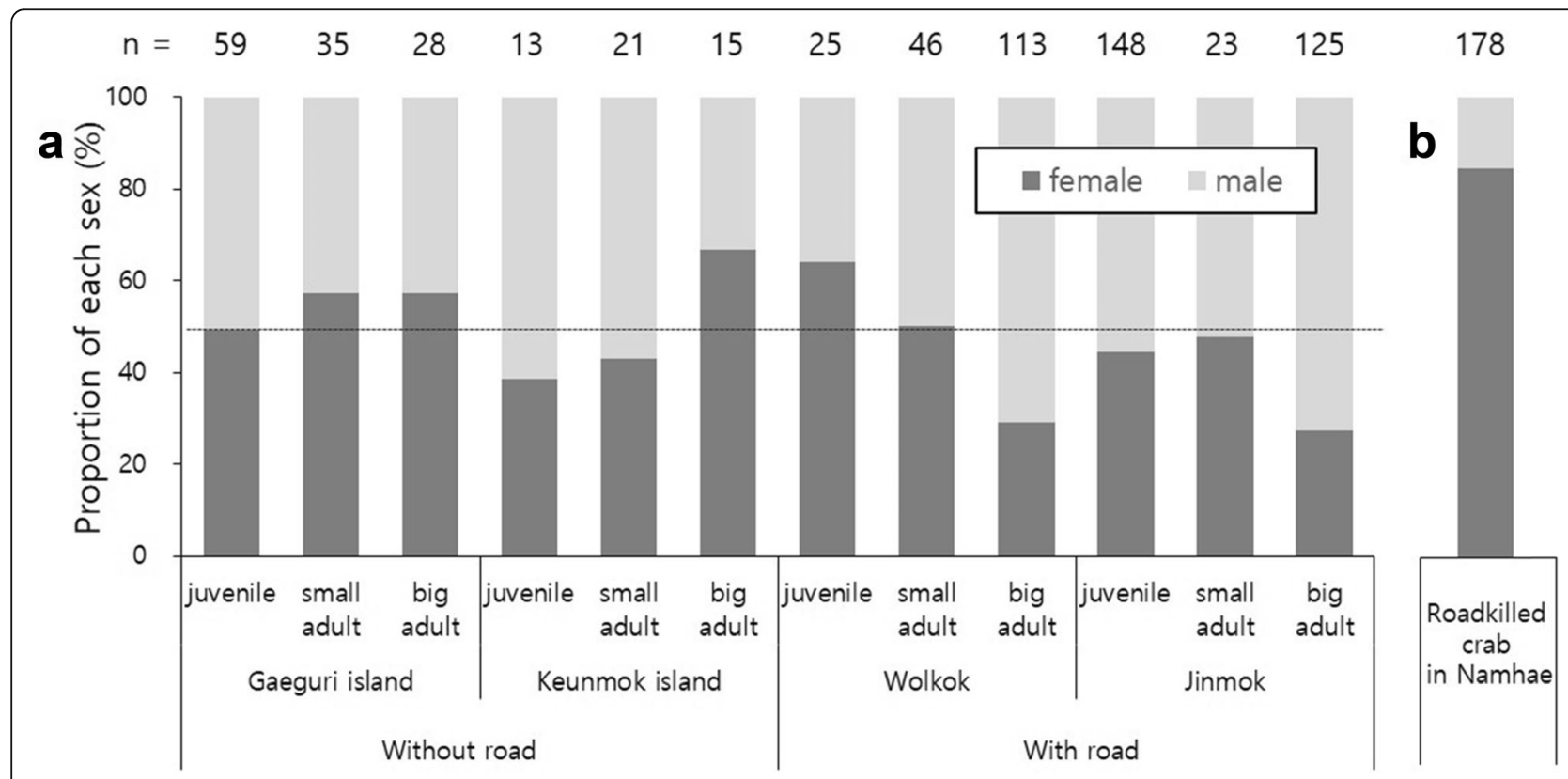

Fig. 2 Comparison of the sex distribution in habitat with coastal road and without road (a). Roadkilled crabs of each sex on coastal road during breeding season $(\mathbf{b})$ 
artificial structures on the coasts are becoming a bigger obstacle to the movement of animals. In particular, the coastal roads between land habitat and sea caused female land crabs more vulnerable to direct roadkill. In the case of black land crab, the proportion of roadkilled crabs also was female skewed significantly, which might threaten the local population (Baine et al. 2007). Hartnoll et al. (2009) also documented the predominant female dead specimens of a land crab (J. lagostoma) near the shore.

Population of the adult land crabs in habitats with coastal road was significantly male biased in this study. However, in earlier study, the proportion of adult males in land crab population was less numerous than females but closer to 50\% during the active season (Suzuki 1981). Similarly, we found that the percent of adult males ranged from 42.9 to 45.7 in habitats without road (uninhabited islands) compared to 64.8-70.4 in habitats with coastal roads. In particular, adult land crabs in Jinmok showed more male biased than Wolgok because coastal roads are closer and bisect between the habitat and the sea completely. There might be a limit to comparison due to the small sample size of the result of the Keunmok Island. On small islands, there are few mammals that could become predators for the land crabs, so comparisons could be limited.

When we compared by dividing adult crabs in Jinmok into small adults and big adults, the proportion of the big adult female crabs (older than the sixth year) was lower than small adult female crabs (from the third year to the fifth year old). Similarly, the proportion of female crabs has gotten smaller with the increase of crab size in Wolkok. The proportion of big adult females ranged only from 27.2 to 29.2 compared to 50-52.2 in small adult females.

The male crabs tend to be larger than female at mature, and this is observed in several species (Leme 2006; Benetti and Negreiros-Fransozo 2003; Litulo 2005; Hartnoll 1982; Hirose and Negreiros-Fransozo 2008; Mokhtari et al. 2008). This sexual dimorphism in size can be explained from the more resource expending by females for reproduction, whereas males have a faster growth rate (da Silva Castiglioni et al. 2011; Hartnoll 2006; Hartnoll et al. 2009). This means male crabs are expected to be more abundant in the larger size classes. However, in the case of S. haematocheir, it was reported that the proportion of male and female was similar in the large size (Suzuki 1981). In addition, in this study, there was no bias among the places where there was no effect of the coastal road. Thus, it is difficult to interpret that male bias in the size of a big adult is a result of natural growth. Therefore, male biased sex ratios of mature land crabs around coastal roads in this study are likely explained by skewed mortality of females struct by automobiles during annual breeding migration. Moreover, land crab species release multiple clutches of eggs each year (Suzuki 1981) which would further increase the risk of repeated road mortality in habits fragmented by coastal roads.

In conclusion, the sex ratios of adult land crabs were significantly male biased at land habitats with the coastal roads due to the fact that the female land crabs were roadkilled during the breeding migration. Since females are exposed to the risk of annually repeated roadkills, the proportion of females likely to be decrease rapidly as they are getting older and larger. This change might be the result of increased artificial structures by industrialization in the coastal areas. This gender bias can lead to a local population decline. Moreover, as the number of eggs carrying is correlated with the female crab size (Fielding and Haley 1976), the disappearance of large females further reduces potential egg productivity, which will reduce the local population size rapidly. In the Hawaiian islands, a land crab (Geograpsus sp.) has become extinct after human colonization (Paulay and Starmer 2011). In order to conserve land crabs as keystone species of coastal forest, long-term roadkill monitoring and roadkill mitigation measures research will be required.

\section{Acknowledgements}

Not applicable.

\section{Authors' contributions \\ MR and JGK conceived ideas and participated in the design of the study. MR collected data and wrote the manuscript draft. JGK edited the manuscript draft. All authors read and approved the final manuscript. \\ Funding \\ None \\ Availability of data and materials \\ The datasets during and/or analyzed during the current study are available from the corresponding author on reasonable request.}

Ethics approval and consent to participate

Not applicable.

Consent for publication

Not applicable

Competing interests

The authors declare that they have no competing interests.

\section{Author details}

${ }^{1}$ Graduate School of Interdisciplinary Program in Environmental Education, Seoul National University, 1 Gwanak-ro, Gwanak-gu, Seoul 08826, Korea.

${ }^{2}$ Department of Biology Education, Seoul National University, 1 Gwanak-ro, Gwanak-gu, Seoul 08826, Korea. ${ }^{3}$ Center for Education Research, Seoul National University, 1 Gwanak-ro, Gwanak-gu, Seoul 08826, Korea.

Received: 25 August 2020 Accepted: 22 September 2020

Published online: 01 October 2020

\section{References}

Airoldi L, Turon X, Perkol-Finkel S, Rius M. Corridors for aliens but not for natives: effects of marine urban sprawl at a regional scale. Divers Distrib. 2015;21: 755-68. https://doi.org/10.1111/ddi.12301.

Aresco MJ. The effect of sex-specific terrestrial movements and roads on the sex ratio of freshwater turtles. Biol Conserv. 2005;123:37-44. https://doi.org/10. 1016/j.biocon.2004.10.006. 
Baine M, Howard M, Taylor E, James J, Velasco A, Grandas Y, Hartnoll R. The development of management options for the black land crab (Gecarcinus ruricola) catchery in the San Andres Archipelago. Colombia. Ocean Coast Manag. 2007:50(7):564-89. https://doi.org/10.1016/j.ocecoaman.2007.02.007.

Benetti AS, Negreiros-Fransozo ML. Symmetric chelipeds in males of the fiddler crab Uca burgersi Holthuis, 1967 (Decapoda, Brachyura, Ocypodidae) Nauplius. 2003;11(2):141-4.

Bishop MJ, Mayer-Pinto M, Airoldi L, Firth LB, Morris RL, Loke LHL, Hawkins SJ, Naylor LA, Coleman RA, Chee SY, Daffron KA. Effects of ocean sprawl on ecological connectivity: impacts and solutions. J Exp Mar Biol Ecol. 2017;492: 7-30. https://doi.org/10.1016/j.jembe.2017.01.021.

Burt JA. The environmental costs of coastal urbanization in the Arabian Gulf. City. 2014;18(6): 760-770.

Caswell H. Matrix population models: construction, analysis, and interpretation. Sunderland: Sinauer Associates; 2001

Coffin AW. From roadkill to road ecology: a review of the ecological effects of roads. J Transp Geogr. 2007;15(5):396-406. https://doi.org/10.1016/j.jtrangeo. 2006.11.006.

da Silva CD, de Oliveira PJA, da Silva JS, Coelho PA. Population dynamics of Sesarma rectum (Crustacea: Brachyura: Grapsidae) in the Ariquinda River mangrove, north-east of Brazil. J Mar Biol Assoc UK. 2011;91(7):1395-401. https://doi.org/10.1017/S0025315411000130.

Fielding A, Haley SR. Sex ratio, size at reproductive maturity, and reproduction of the Hawaiian kona crab, Ranina ranina (Linnaeus) (Brachyura, Gymnopleura, Raninidae). Pac Sci. 1976;30:131-45.

Hartnoll RG. Growth. pp. 111-196 in The Biology of Crustacea, Volume 2: Embryology, Morphology, and Genetics, Abele LG ed., Volume 2. 1982. New York: Academic Press.

Hartnoll RG. Reproductive investment in Brachyura. Hydrobiologia. 2006;557(1): 31-40. https://doi.org/10.1007/s10750-005-9305-6.

Hartnoll RG, Broderick AC, Godley BJ, Saunders KE. Population structure of the land crab Johngarthia lagostoma on Ascension Island. J Crust Biol. 2009;29(1): 57-61. https://doi.org/10.1651/08-2992.1.

Hirose GL, Negreiros-Fransozo ML. Population biology of Uca maracoani Latreille 1802-1803 (Crustacea, Brachyura, Ocypodidae) on the south-eastern coast of Brazil. Pan-Am J Aquat Sci. 2008;3(3):373-83.

Le Galliard J-F, Fitze PS, Ferrière R, Clobert J. Sex ratio bias, male aggression, and population collapse in lizards. PNAS. 2005;102(50):18231-6. https://doi.org/10. 1073/pnas.0505172102.

Leme MHA. Seasonal changes in reproductive traits of the crab Sesarma Rectum (Grapsoidea: Sesarmidae) on the northern coast of São Paulo State, Brazil. J Crust Biol. 2006;26(2):141-7. https://doi.org/10.1651/C-2621.1.

Lindquist ES, Krauss KW, Green PT, O'Dowd DJ, Sherman PM, Smith TJ. Land crabs as key drivers in tropical coastal forest recruitment. Biol Rev Camb Philos Soc. 2009;84:203e223. https://doi.org/10.1111/j.1469-185X.2008.00070.x.

Litulo C. Population biology of the fiddler crab Uca annulipes (Brachyura: Ocypodidae) in a tropical East African mangrove (Mozambique). Estuar Coast Shelf S. 2005;62:283-90. https://doi.org/10.1016/j.ecss.2004.09.009.

Liu H-C, Jeng M-S, Hartnoll RG. Moulting of the semi-terrestrial crab Chiromantes haematocheir (de haan, 1833) (Decapoda, Sesarmidae). Crustaceana. 2017 90(14):1731-45. https://doi.org/10.1163/15685403-00003711.

Luppi TA, Spivak ED, Anger K. Experimental studies on predation and cannibalism of the settlers of Chasmagnathus granulata and Cyrtograpsus angulatus (Crachyura: Grapsidae). J Exp Mar Biol Ecol. 2001;265:29-48. https://doi.org/10. 1016/S0022-0981(01)00322-7.

Miyake K, Ura K, Shinnosuke C, Yoshiki U, Yasunori B, Kusube T, Yanai S. Guaiacol oxidation activity of herbivorous land crabs, Chiromantes haematocheir and Chiromantes dehaani. J Biosci Bioeng. 2019;128(3):316-22. https://doi.org/10. 1016/j.jbiosc.2019.02.012.

Mokhtari M, Savari A, Rezai H, Kochanian P, Bitaab A. Population ecology of fiddler crab, Uca lactea annulipes (Decapoda : Ocypodidae) in Sirik mangrove estuary. Iran. Estuar Coast Shelf S. 2008;76(2):273-81. https://doi.org/10.1016/j. ecss.2007.07.010.

Mumme RL, Schoech SJ, Woolfenden GE, Fitzpatrick JW. Life and death in the fast lane: demographic consequences of road mortality in the Florida scrubjay. Conserv Biol. 2000;14:501-12. https://doi.org/10.1046/j.1523-1739.2000. 98370.x.

Paula J. Rhythms of larval release of decapod crustaceans in the Mira Estuary. Portugal. Mar Biol. 1989;100:309-12. https://doi.org/10.1007/BF00391144.

Paulay G, Starmer J. Evolution, insular restriction, and extinction of oceanic land crabs, exemplified by the loss of an endemic Geograpsus in the Hawaiian
Islands. PLoS One. 2011;6(5):e19916. https://doi.org/10.1371/journal.pone. 0019916.

Saigusa M. Ecological distribution of three species of the genus Sesarma in winter season. Zool Mag. 1978;87:142-50.

Saigusa M. Adaptive significance of a semilunar rhythm in the terrestrial crab Sesarma. Biol Bull. 1981;160:311-21. https://doi.org/10.2307/1540891.

Saigusa M. Hatching of an estuarine crab, Sesarma haematochier: factors affecting the timing of hatching in detached embryos, and enhancement of hatching synchrony by the female. J Oceanogr. 2000;56:93-102. https://doi.org/10. 1023/A:1011118726283.

Saigusa M, Hidaka T. Semilunar rhythm in the zoea-release activity of the terrestrial crabs Sesarma. Oecologia. 1978;37:163-76. https://doi.org/10.1007/ BF00344988.

Sekovski I, Newton A, Dennison WC. Megacities in the coastal zone: using a driver-pressure-state-impact-response framework to address complex environmental problems. Estuar Coast Shelf S. 2012;96:48-59. https://doi.org/ 10.1016/j.ecss.2011.07.011.

Suzuki S. The life history of Sesarma haematocheir in the Miura peninsula. Res Crust. 1981;11:51-65. doi:10.18353/rcustacea.11.0_51.

\section{Publisher's Note}

Springer Nature remains neutral with regard to jurisdictional claims in published maps and institutional affiliations.
Ready to submit your research? Choose BMC and benefit from:

- fast, convenient online submission

- thorough peer review by experienced researchers in your field

- rapid publication on acceptance

- support for research data, including large and complex data types

- gold Open Access which fosters wider collaboration and increased citations

- maximum visibility for your research: over $100 \mathrm{M}$ website views per year

At BMC, research is always in progress.

Learn more biomedcentral.com/submissions 